\title{
One Man's Plan: The Story of Gerald Melling's Tenure as Editor of New Zealand Architect, and some Implications Thereof
}

\author{
Peter Wood, School of Architecture, Victoria University, Wellington
}

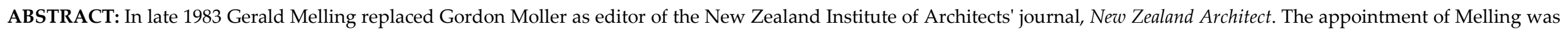

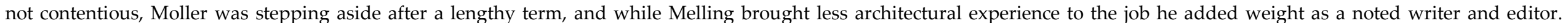

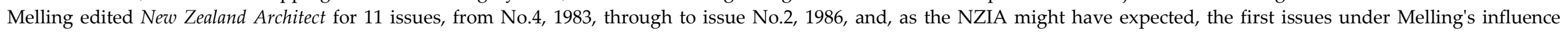

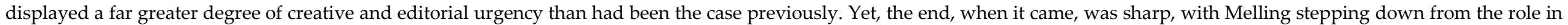

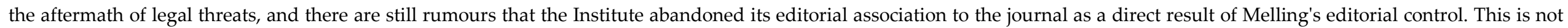
true, and this paper traces the circumstances of that myth.

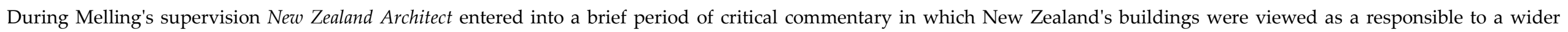

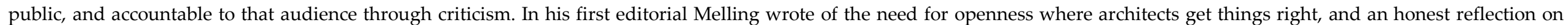

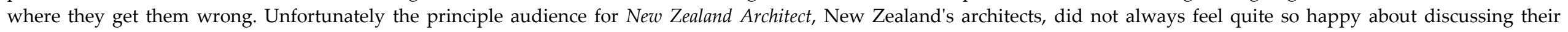

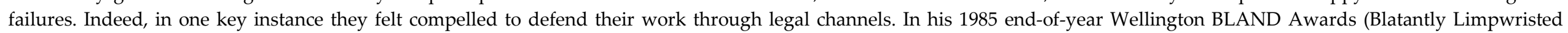

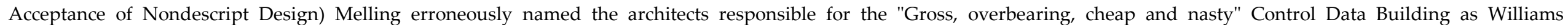

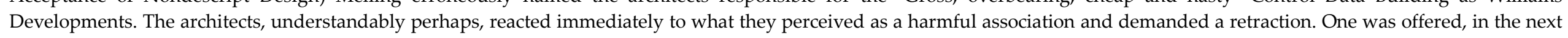

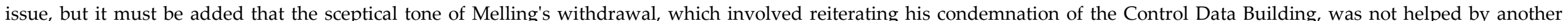

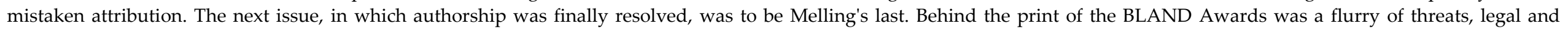
otherwise, which called into attention the financial responsibility held by the NZIA in the advent of legitimate claims of slander being upheld, soon after Melling stepped down.

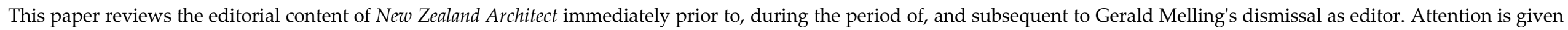

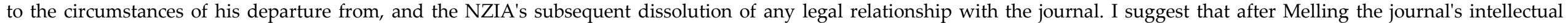

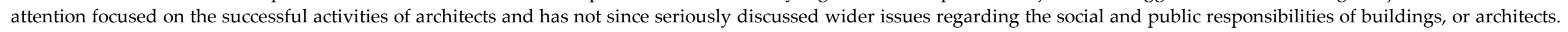

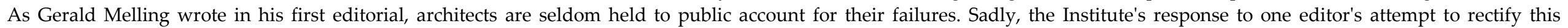
oversight set its own journal on a course of social disengagement from which it has never been able to recover.

In Myth and Meaning Levi-Strauss suggests that myths have no authors but are created imperceptibly in transmission, across great distances and generations, and are the result of many voices. ${ }^{1}$ Moving from primitive Amerindian mythology to New Zealand in

\footnotetext{
${ }^{1}$ Lévi-Strauss Myth and Meaning: Five Talks for Radio
}

the 1980s is, I admit, a bit of a stretch, but sometimes New Zealand architecture does feel more like an ethnographically distinct subculture than a broader cultural discipline, ${ }^{2}$ so perhaps it's not too much to suggest that myth might play a part in organizing this

${ }^{2}$ Hebdige Subculture, the Meaning of Style alternative community also. ${ }^{3}$

By way of example I wish to focus on Gerald Melling's tenure as editor of the New Zealand

${ }^{3}$ For example, see my discussion on the importance of The Elegant Shed in the construction of New Zealand's recent architectural history. Wood "Watershed: Of Buildings and Stories and Elegant Sheds" pp 72-80. 
Institute of Architects' industry journal, New Zealand Architect, in the mid 1980s. As a student in the later 1980s the version I knew was of Melling as an upstart editorial appointment, more poet than architect, who threw caution to the wind in his attempts to enliven architectural criticism in New Zealand. His provocative "Finial" column, and contrived award schemes, were risky sensationalism not fitting of a professional organization, and they resulted in an embarrassing legal action which was financially costly for the New Zealand Institute of Architects, prompting them to abandon editorial control of the Journal to a commercial publisher, thus censoring the NZIA's voice for architectural criticism in print, and all this lead to Melling's dismissal. The reality (and I here I use that word with some caution) is both more ordinary and more instructive.

In late 1983 Gerald Melling replaced Gordon Moller as editor of the New Zealand Institute of Architects' journal, New Zealand Architect. The appointment of Melling was not contentious, Moller was stepping aside after a lengthy term, and while Melling brought less architectural experience to the job he added literary weight as a noted writer. Melling edited New Zealand Architect for 11 issues, from No. 4, 1983, through to issue No. 2, 1986, and, as the New Zealand Institute of Architects (NZIA) might have expected, the first issues under Melling's influence displayed a far greater degree of creative and editorial experimentation than had previously been the case

During Melling's supervision, New Zealand Architect entered into a brief period of critical commentary in which New Zealand's buildings were viewed as being responsible to a wider public, and accountable to that audience through criticism. In his first editorial Melling wrote of the need for acknowledgement where architects get things right, but also honest reflection on where they get them wrong. Unfortunately the main audience for New Zealand Architect, New Zealand's architects, did not always feel quite so chirpy about how architectural authorship was attributed. Indeed, in one key instance they felt compelled to defend their reputation through legal channels. Such was the case with the very unofficial 1985 Wellington BLAND Awards where Melling erroneously attributed two projects, to the dismay of the architects named.
The architects involved, understandably perhaps, reacted to what they perceived as a harmful association and demanded retractions. One was offered, in the next issue, but it must be added that the sceptical tone of Melling's withdrawal, which involved reiterating his condemnation, was not helped by another mistaken attribution. The next issue, in which authorship was finally resolved, was to be Melling's last. Behind the print of the BLAND Awards was a flurry of threats, legal and otherwise, which called into attention the financial responsibility held by the NZIA in the advent of legitimate claims of slander being upheld. At least that was the story passed down.

Melling's suitability for appointment as editor of New Zealand Architect was in stark contrast to his predecessor, Gordon Moller. While the latter largely represented successful architectural practice in the common professional sense, Melling's appointment drew as much on his literary experience more, perhaps - than it did his architectural record. In his first editorial column Melling announced his commitment to the role of the critic, describing criticism as a fraught but necessary activity for the well-being of the 
profession in New Zealand. ${ }^{4}$ Reflecting on his time as editor 22 years later he was more circumspect, admitting to the limits of criticism in a modest community:

In a small country like New Zealand, however, criticism - in any field - is particularly onerous. The critic is confronted by the criticised in the local dairy whilst buying a bottle of milk, the contents of which may spill - like blood - upon the floor. Thus are we content with the slanderous commentaries of private social gatherings. ${ }^{5}$

There can be no doubt that in large part Melling's disillusionment with criticism can be traced back to his experience with "Finial," the "anonymous" column he introduced to the journal. Described as an "anonymous columnist firmly dedicated to the possibility of architectural excellence" there was never any real uncertainty that "Finial" was Melling attempting to stimulate critical dialogue through an artificial persona, which it did. The first column took issue with the amount of work Christchurch resident Miles Warren was contributing to Wellington's Golden Mile redevelopment, not so much for the quality of building but for the general lack of public awareness that one architect was doing so

${ }^{4}$ Melling "Editorial" (1983) (4):5.

${ }^{5}$ Melling "Scouse Editor Kops Red Card" p 84. much. ${ }^{6}$ Subsequent installments continued in this vein: attempts to neuter Roger Walker's brilliance by various regulatory bodies, ${ }^{7}$ an attack on the pointlessness of the Wellington Harbour Commission competition, ${ }^{8}$ an exposé on the corporate pressure behind the BNZ Building in the Capitol, and, by the fifth issue, the phenomena of copycat PoMo barrel-vaults in Wellington that may or may not have been influenced by a cover of the Architecture Review. Melling's use of an anonymous critical column was inspired, and if "Finial" had one major failing, it was that it was biased towards the editor's hometown.

The real problems began when "Finial" - by now an entity and not just a column - wrote of "the snoring [that] emanates from the offices of Morrison Cooper and Partners," and that firm's role in the redevelopment of the Wellington Club. ${ }^{9}$ "Finial" went on to suggest that the named architects, in accepting (however tacitly) the destruction of Roger Walker's existing Club building, were in violation of Principle 2 of the Code of Practice and Professional Conduct. Namely, that

${ }^{6}$ Melling "Finial: The Golden Miles" p 9.

${ }^{7}$ Melling "Finial: One more unto the breach ..." p 9

${ }^{8}$ Melling "Finial: A Laugh a minute ..." p 9.

${ }^{9}$ Melling "A Matter of Conscience" p 9.
Morrison Cooper and Partner's were pursuing a course of action that would bring into doubt their professional integrity and that of the profession a whole. In principle the issue here was an interesting one, although more a case of disciplinary ethics or architectural morality than pure criticism. What broader responsibility, asked "Finial," does one architect have for the work of another, and especially so in a corporate climate where architects, despite Institutional associations and Acts of Statue, are still in competition.

One kind of answer appeared in the following issue, which did not have its regular "Finial" column, although it did print an apology to Morrison, Cooper and Partners, acknowledging that the imminent destruction of Walker's Club building was not due to any initiative on the part of the architects. It read, in part:

comments were made in the article from which it could be inferred that Morrison Cooper and Partners may have been guilty of commercial rape of the environment, acted without integrity or conscience and were in breach of the Architects' Code of Practice and Professional Conduct. It is accepted that these comments were unwarranted and no such inferences are justified. ${ }^{10}$

\footnotetext{
10 "Apology to Morrison Cooper \& Partners" p 11.
} 
Reading between the lines of apology, Morrison Cooper and Partners seem to be arguing that the architect is a mere servant to a client's wishes, and while they should bring professional diligence to any job they have no more power to redefine a client's wishes than a maid does to question an untidy room.

Two months later, "Finial" was back in full flight, fuelling the flames of opinion set by Martin Hanley four months earlier in his attack on the Victoria University School of Architecture, and then, for good measure, a slap was taken at John Blair for being derivative. ${ }^{11}$

One has to be attuned to small print to spot a further apology on the index page in which the New Zealand Institute of Architects acknowledges making a full and final settlement with Morrison Cooper and Partners for their legal costs and reimbursement for loss of time in dealing "with this matter."12

If, through 1985, some degree of progress had been made toward balanced criticism in the

\footnotetext{
${ }^{11}$ Melling "Finial: Limited Design" p 11.

12 "With this Matter" p 5.
}

journal (that is to say, less judgmental criticism) then it began to unravel again in the last issue of the year with "Finial"'s announcement of the Wellington BLAND Awards. BLAND - or, Blatantly Limpwristed Acceptance of Nondescript Design - was described by Finial as the "natural" successor to 1984's Wellington Awards for Minimum Architecture. The MAP Awards had quietly slipped through, probably due to it being a broad criticism of the architectural quality in Wellington's recent building boom, rather than any specific outing of inadequacy (although it did accuse Morrison, Cooper and Partners of "opting out" of the design process with the Foreign Affairs Building). The BLAND Awards offered no concessions. Morrison, Cooper and Partners were again singled out for repeating their failings, and an office block by Peddle Thorpe and Maidens was found to be "quite grotesquely unsympathetic."13 However, even by "Finial"'s standards the published view of Williams Developments design for the Control Data Building was fierce: "Gross, overbearing, cheap and nasty ... In a word, hideous." 14

\footnotetext{
${ }^{13}$ Melling "Finial: 1985 Wellington BLAND Awards" $\mathrm{p}$ 12.

${ }^{14}$ Melling "Finial: 1985 Wellington BLAND Awards" p
}

1986 began with a full page retraction. ${ }^{15}$ Williams Developments, it appeared, were not the architects of the Control Data Building, and an apology was issued to $\mathrm{N}$ Anthony Corry, Director of Williams Architectural Division, for the error. If ever there was a backhanded act of contrition then this was it. Provocatively, Melling had laid out the retraction to emphasise a repeat printing of the original "Finial" entry, complete with condemnation, and at the same time had managed to specifically name an architect who might otherwise have remained invisible behind their corporate moniker. It was inevitable that this would not put an end to the matter.

The second edition for 1986 began with yet another admission. "We goofed again" wrote Melling in the first line of his last editorial. ${ }^{16} \mathrm{It}$ was Curran Developments and not Williams Group who were responsible for the Control Data Building although, as Melling points out, such a distinction really makes no meaningful difference. ${ }^{17} \mathrm{He}$ ended with a requirement to the architect. Just when, he asks, is an architect a mere architect: "One wonders if he

\footnotetext{
15 "Apology and Retraction to the Williams Group" p 14. ${ }^{16}$ Melling "Editorial" (1986) 2:5.
}

${ }_{17}$ Melling "Editorial" (1986) 2:5. 
really knows; or (dare one even suggest it?) cares ..."18

It is a hollow conclusion to what had otherwise been an exciting if flawed attempt at genuine critical architectural engagement in a community that appeared too small and insular to understand let alone accept the role of the critic. "Finial" had one last gasp in the form of a full-page cartoon by Malcolm Walker, which parodied the earlier apology to Morrison Cooper and Partners the fictional firm of Turbo, Floss and Dollop declaring their regret to the "civilized world" for their shameful errors. ${ }^{19}$ And then it was over, Melling was out, and the appointment of his replacement, John Huggins was announced. Only 10 years later I came to hear rumour of the radical editor who was fired because he dared to speak out against the mediocre and the moribund. In mere months, it seemed, the story of a critically insecure profession had risen but, despite what we may want to believe critical commentary of the kind that Melling adopted, this was not new to architectural journalism. As long ago as the 1890s, the editor of the Architecture Review,

${ }^{18}$ Melling "Editorial" (1986) 2:5.

${ }^{19}$ [Walker] "Finial: New Zealand Architect" p 8
Montgomery Schuyler, ran a regular column titled "Architectural Aberrations" in which in exposed buildings he believed to be architectural deficient. ${ }^{20}$ Melling has recalled taking the idea of "Finial," for his anonymous column for criticism in brief, from "Astragal," a similarly pitched commentary used in the Architects' Journal. ${ }^{21}$

"Finial," with its characteristically caustic wit, would be the undoing of the New Zealand Architect, but not Melling, as we shall see. But for now it is useful to emphasise just how dependent the changes to the journal were on its new editor. Melling wrote most articles, rewrote those of others, produced the graphics and laid out the gallery sheets (not, he is at pains to point out, on his kitchen but his office table, thus ending one myth-making possibility), and "endlessly" proof-reading. The results, ironically enough, were not without criticism, particular on the question of how projects were selected for inclusion ("Genuinely interesting buildings choose themselves"22).

${ }^{20}$ Smith "Montgomery Schuyler and the History of American Architecture."

${ }^{21}$ Melling "Scouse Editor Kops Red Card" pp 83-84.

${ }^{22}$ Melling "Scouse Editor Kops Red Card" p 84.
Melling has admitted the Architectural Review was a "graphic model"23 for the journal under his influence, and that he was the graphic artist due to measures of economy and control. It is likely that his experience of the Review would have included the period of publication known as the "MANPLAN" issues (1969) when the editors engaged photojournalists - pointedly not architectural photographers - to document post-war architecture and planning. ${ }^{24}$ These issues employed photography rather than words as a measure of criticism against the world created by architects and planners after 1945, and while New Zealand was geographically and economically removed from those conditions, Melling's personal history was much closer to a baby-boom childhood in Liverpool.

The MANPLAN issues, were graphically striking but not popular with the Architectural Review's principle readership: architects. As Nancy Woods has observed, "the imagery and minimal text vented the anger, anxiety, despair, and frustration caused by modernism there accustomed to cosseting by the

${ }^{23}$ Melling "Scouse Editor Kops Red Card" pp 83-84. ${ }^{24}$ Williams "Representing Architecture" pp 285-296. 
professional press, many architects were outraged and cancelled their subscriptions." 25 The pictorial emphasis in MANPLAN means it was probably more an archetype than a direct publication model. Indeed, there is a strong graphical continuity between the editorships of Moller, Melling, and that of Melling's successor, John Huggins.

However, one notable interruption to cover format occurred with the first issue edited by Huggins. In an atypical move the cover shunned a building to feature the crest of the New Zealand Institute of Architects. It was the awards issue for 1986, but even so it is hard not to read this decision as a reconciliatory gesture towards those architects who had felt maligned, marginalized or alienated over the last 18 months (if, I would add, such a group ever existed). With the authority of professional practice so obviously spread across the new editorship, within two issues the "problem" areas of the journal were remedied. "Finial," so obvious the voice of Melling, was gone, as too was the "Letters" page and any attempt at provocative award schemes.

\footnotetext{
${ }^{25}$ Woods Beyond the Architect's Eye p 262.
}

Overall the level of intellectual engagement was diluted, to be replaced by descriptive, rather than critical, commentary. Huggins' first editorial was a declaration for this new empire of support and enthusiasm, but it does not help that it was barely legible, offering complication without complexity, idiotically ambitious in scope, and utterly depressing in execution (and with an irritating pattern of using formatting to emphasise points that would otherwise not be visible for their lack of point). With every florid flourish he painfully exhibited his lack of literary and critical measure against Melling, as his painful assessment of the NZIA Awards makes so apparent. Huggins wrote:

In the end, of course, new work like a curtain, lifts the veil both of history and now - at the edge of the unknown. The buildings singled out for the National Awards are buildings and environments in which such gestures, as one person waves to another across how many centuries ARE QUITE CLEAR. ${ }^{26}$

His final editorial was similarly a limp affair. Like his very first it was a bombastic exercise in dropping names from literature and science as though this in itself would account for the balance of poetry and technology found in

${ }^{26}$ Huggins "Through the Eyes of the New Editor" p 14. architecture. Missing, right to the end, an opinion, his categorical statement that "It is not true that architects cannot write" was a whiny snipe that would have carried more weight if he wrote better. Huggins' editorial tenure ended with number 5, 1987, a lacklustre Special Issue in which Russell Walden played torpid overtures to Le Corbusier on the centenary of the great architect's birth.

And then New Zealand Architect ceased to exist, and in its place was Architecture New Zealand, with an editor appointed not by the New Zealand Institute of Architects, but by AGM, the journal's commercial publishers. The new editor was Carol Bucknell, who brought industry experience having been a member of the Architectural Journal in London.

The journal's reinvention began with a distinctly familiar flavour with a guest editorial from Gordon Moller. ${ }^{27}$ In it Moller picked up very much where he had left off in $1983,{ }^{28}$ emphasising commercial building and offering his view that architects are not really in competition with each other, but with

${ }^{27}$ Moller "Guest Editorial" p 36.

${ }^{28}$ Moller "Guest Editorial" p 36. 
society and economics at large. Moreover, in what was only a short comment, Moller managed to use the word "debate" six times without once mentioning the role of criticism. ${ }^{29}$ Instead, architects were encouraged to "participate," "comment," and offer "contributions." In Moller's opinion architects are a species under threat, and internal division, fuelled by "criticism" that undermines and dilutes the authority of the architect. He notes the architect's place as a builder of society: better to "debate" outwardly than offer divisive criticism inwardly (how different this was to Melling's first editorial where he defended the critic and by default criticism - as an agent of social responsibility).

With hindsight, Melling's editorship looks like a glorious moment in the otherwise perfectly respectable history of the New Zealand Institute of Architects' Journal. It is tempting to view it as a moment of intellectual crisis, and resolution in the Institute's attitude to critical

${ }^{29}$ Moller does use the word "criticism" but only in the context of concerns that some architects had that the Institute of Architects was losing control over the journal. In this regard what he actually means is "critical," and it is interesting that he studious avoids using the term in an architectural direction. appraisal, but I doubt this argument can be maintained at length. As proof, and for the record, I asked Melling about his sacking. His answer: "no, never."30 While there was the embarrassing litigation described above he was never fired, instead stepping down naturally at the end of his contract period. He in fact received resounding support from architects throughout the country and I wonder how much his successor's editorial neutrality created a greater reason for disenfranchising the journal. If nothing else, under Melling, the New Zealand Architect was contentious, audacious and provocative - all things Melling said architecture needed to be. The no-risk approach taken by Huggins was legally desirably, perhaps, but it was also generic in scope and bland in execution, and this made it all the easier to promote professionalism above expertise in editorship.

\footnotetext{
${ }^{30}$ Melling, Pers Comm.
} 


\section{REFERENCES}

"Apology to Morrison Cooper \& Partners" New Zealand Architect (1984) 5:11.

"Apology and Retraction to the Williams Group" New Zealand Architect (1986) 1:14.

Hebdige, Dick Subculture, the Meaning of Style: London: Methuen, 1979.

Huggins, John "Through the Eyes if the New Editor" New Zealand Architect (1986) 3:14-23.

Lévi-Strauss, Claude Myth and Meaning: Five Talks for Radio: Toronto \& Buffalo: University of Toronto Press, c1978.

Melling, Gerald "A Matter of Conscience" New Zealand Architect (1984) $4: 9$.

Melling, Gerald "Editorial" New Zealand Architect (1983) 4:5.

Melling, Gerald "Editorial" New Zealand Architect (1986) 2:5.

Melling, Gerald "Finial: The Golden Miles" New Zealand Architect (1983) $4: 9$

Melling, Gerald "Finial: One more unto the breach... " New Zealand Architect (1983) 5:9

Melling, Gerald "Finial: A Laugh a minute ..." New Zealand Architect (1983) 6:9

Melling, Gerald "Finial: 1985 Wellington BLAND Awards" New Zealand Architect (1985) 6:12.

Melling, Gerald "Finial: Limited Design" New Zealand Architect (1985) 3:11.

Melling, Gerald. Personal communication (interview in person), 20 November 2009.

Melling, Gerald "Scouse Editor Kops Red Card." Architecture New Zealand (January/February 2005) 1:84.

Moller, Gordon "Guest Editorial" Architecture New Zealand (November/December 1987):36
Smith, Edward R. "Montgomery Schuyler and the History of American Architecture" Architectural Record (September 1914) XXXVI(3):264-267.

[Walker, Malcolm] "Finial: New Zealand Architect" Architect New Zealand (1986) 2:8.

Williams, Richard "Representing Architecture: The British Architectural Press in the 1960s" Journal of Design History (1996) 9:285-296

"With this Matter" New Zealand Architect (1984) 6:5.

Wood, Peter "Watershed: Of Buildings and Stories and Elegant Sheds." Exquisite Apart: 100 Years of Architecture in New Zealand. Ed. Charles Walker. Auckland: Balasoglou Books, New Zealand Institute of Architects, 2005:72-80.

Woods, Mary N. Beyond the Architect's Eye: Photographs and the American Built Environment. Philadelphia: University of Philadelphia Press, 2009. 